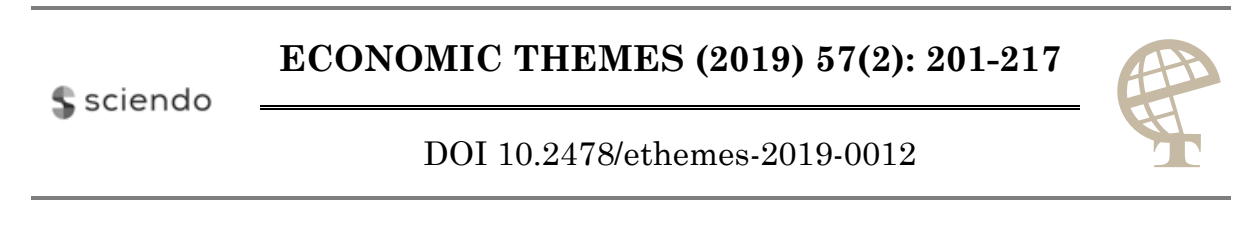

\title{
MEASURING CLIENTS' ATTITUDES ABOUT BANKING SERVICES QUALITY USING THE SERVQUAL MODEL
}

\author{
Jovana Savić \\ University of Kragujevac, Faculty of Economics, Republic of Serbia \\ 凶javic@kg.ac.rs \\ Nevena Veselinović \\ Megatrend University, Faculty for Management Zajecar, Republic of Serbia \\ $\triangle$ nveselinovicc@gmail.com
}

UDC

336.71:

658.6

Original scientific paper

\begin{abstract}
The economic crisis and the emergence of an increasing number of competitors in the banking sector have led to the need for banks to better understand their clients and to work more closely together with them. The basis of survival and profitable business of banks is the achievement of high quality offer that is the asset for developing long-term relationships. The aim of the paper is to determine the effects of the banking services quality dimensions on satisfaction and loyalty of clients using modified SERVQUAL model. The main research question is to examine which dimensions of banking services quality have an effect on the satisfaction and loyalty of clients, what is the nature and the intensity of this impact. For the purpose of measuring clients' attitudes regarding banking services quality, the survey method, questionnaire technique was applied. The questionnaire was distributed to clients of banks operating in the territory of Kragujevac, Central Serbia, in the period from September to October, 2018. Simple random sample technique for sampling was applied. The analysis was conducted by processing the primary data in statistical software SPSS where several statistical analyses were conducted. Based on multiple regression analysis, it came to the result that the strongest influence on clients' satisfaction has variable empathy and the weakest variable tangibility, while variable reliability has no influence. On the other hand, clients' loyalty is most strongly influenced by variable responsiveness while the weakest influence, as well as on satisfaction, has variable tangibility. The paper points to the significance of improving banking services quality in order to achieve higher level of satisfaction and long-term clients' loyalty, which is particularly important when it comes to dimensions that have weak or no influence on the observed aspects of consumer behaviour.
\end{abstract}

The research was conducted within the III 41010 project of the Ministry of Science, Education and Technological Development of the Republic of Serbia 
Received: Keywords: services quality, banks, clients, SERVQUAL model, satisfaction, 29.01.2019 loyalty

Accepted:

11.07.2019

JEL classification: M30, M31

\section{Introduction}

In recent decades, the financial sector of the Republic of Serbia experienced dynamic changes resulting from the escalation of new technologies, liberalization and deregulation of financial markets, as well as regulatory initiatives at the international level (Ljumovic et al., 2014). Bearing in mind that the financial system of Serbia is bank-based as well as the inevitability of the Serbian capital market, a stable and profitable banking sector becomes an imperative of long-term and sustainable economic growth and development. Dynamics of changes that characterise the business of banking institutions allows the use of different instruments in order to strengthen their market position and improve profitability of business. Comprehensive processes of changes in the banking market as response to the pressure of competition in providing financial services characterises key directions of market evolution, whereby it is especially important to emphasise first and foremost satisfaction and loyalty as the most important ways of achieving long-term relationships with clients, which undoubtedly represents the basis for creating a sustainable competitive advantage. Increased competition in the banking market has led banks to build strong business relationships with clients and, accordingly, to accept the principles of the CRM concept, which put banking clients at the center of banking activities (Marinkovic \& Senic, 2012).

The banking sector of the Republic of Serbia with the total net balance assets of over 3 billion RSD, the average capital adequacy ratio of over $20 \%$ and the liquidity index of over $2 \%$ represents the most developed and leading sector of the Serbian economy (NBS, 2017). According to the data of the National Bank of Serbia, the first quarter of 2018 is characterised by the business of 29 banks, tendency of increasing the total number of employees in the banking sector, as well as the increase in the number of business units, while the majority share in the banking sector of the Republic of Serbia is owned by foreign banks (NBS, 2018). The recent developments in the Serbian banking market clearly point to the processes of acquisition of international banks by domestic buyers. Consolidation in the Serbian banking market is expected, with mergers and sales of banks more certain in the market segment with Greek and Serbian banks.

The most important determinant of clients' satisfaction and loyalty in the banking sector today is service quality. When considering the situation related to services quality in domestic banking sector, Radojević and Marjanović (2011) state that in Serbia banks mainly offer similar services, that the conditions for development of new services are reduced to a minimum, that the differentiation of 
services through promotional activities is more and more difficult due to the greater possibility of copying from competitors, and that the achievement of competitive advantage through prices is unjustified because it leads to fall in profit, which is why the improvement of the service quality is considered as the main source of competitive advantage. Research of Zelenović et al. (2017) showed that clients expect much more from banks in terms of service quality compared to the quality that is provided to them, which points to the need for further research to determine whether and in which segments there is a lack of fulfillment of client expectations and the possibility of improving the service quality which banks are providing. Also, Marinković and Senić (2012) state that it would be desirable to examine the influence of the service supply factors of banks on customer loyalty. According to the author's knowledge, the researches that deal with the analysis of the effects of banking services quality dimensions on clients' satisfaction and loyalty in Serbia are very rare, and taking into account this fact, as well as the previously noted findings, research gap that needs to be supplemented with new knowledge has been identified.

Starting from the significance of the banking services quality for banks' development and functioning on the domestic financial market, on the one hand, with satisfaction and loyalty as a basis for long-term and profitable banking operations, on the other hand, an empirical study was conducted in order to determine the effects of banking services quality dimensions on satisfaction and loyalty of clients using modified SERVQUAL model. The main research question is to examine which dimensions of banking services quality have an effect on the satisfaction and loyalty of clients, what is the nature and the intensity of this impact. The analysis first of all possesses an empirical character in order to avoid giving the authors' subjective assessments regarding the banking services quality. The survey was conducted on the territory of Kragujevac, Central Serbia, and the collected primary data were analysed in statistical software SPSS. The structure of the work consists of several parts. The first part of the paper is devoted to the evaluation of previous theoretical and empirical knowledge about banking services quality and its influence on clients' behaviour viewed through the dimensions of the SERVQUAL model. In the second part of the paper, an analytical tool for the evaluation of banking services quality, which includes the explanation of the SERQUAL model, a description of the questionnaire and the structure of the sample, was presented. The third part of the paper refers to the concretization of the research i.e. the emphasis on the results of the conducted empirical study. In the concluding part, with particular reference to the analysed banking services quality, the main conclusions and recommendations derived from the research and intended for banks were highlighted. The questionnaire by which the primary data on the attitudes of banks clients were collected is given in the appendix. 


\section{Literature review}

Under modern business conditions, a strategically important element of the comprehensive development of service companies have become services quality. The concept of quality, in recent decades, has become the subject of research by numerous authors, undoubtedly because the survival and achievement of the longterm competitive advantage of the company largely depend on its ability to adapt production, technology, product and services quality to contemporary market demands. In spite of the growing interest, regarding the definition of quality among authors there are still divergent attitudes, which makes quality measurement a complex task. Grönroos (1984, p. 39) points out that the quality of services can be classified into: technical dimension of quality - which answers the question of what consumer receives and functional dimension of quality - which answers the question to the way in which consumer receives a particular service. Cronin and Taylor (1992) used a performance-based model and came to the conclusion that services quality should be measured as consumers' attitude and that it is a predictor of consumer satisfaction, while consumer satisfaction has a stronger influence on purchasing intention than on service quality. In their work, Furrer et al. (2000) linked different cultures with the dimensions of service quality and pointed out that relative importance of service quality dimensions varies between different cultures. Parasuraman et al. (1985, p. 48) observe service quality as difference between expectations and perceptions of consumers and develop the model of gaps where, in line with this model, if consumer expectations go beyond achievements, perceived quality is below satisfactory with the tendency of moving towards totally unacceptable quality and increasing difference between expectations and perceptions of consumers.

One of the most frequently used models for measuring services quality that has emerged as a result of a combination of theoretical and practical research is the SERVQUAL model. The authors of SERVQUAL model point out that customer estimates service quality in relation to five quality dimensions: tangibility or the presence of physical elements, reliability in the form of ability to deliver the service in an appropriate manner, responsiveness in the form of readiness to help and provide fast service, assurance in the form of acquisition security of the service provider and empathy or understanding in the form of providing personalized services (Parasuraman et al., 1988).

The SERVQUAL model is widely used in measuring services quality in different sectors of the economy. In order to research services quality in tourism and catering sector, many authors modify the SERVQUAL model by adapting it to the various attributes of services that characterise this field of economy. Saleh \& Ryan (1991) investigating services quality in the hotel industry include 33 questions and define five dimensions of quality: transparency, tangible elements, trust, avoidance of sarcasm and empathy. Starting from the five dimensions of the 
SERVQUAL model, Stevens et al. (1995) developed the DINSERV model that includes 29 questions for measuring service quality in restaurants. Meesala \& Paul (2016) using the SERVQUAL model are researching health care services quality and point out that quality dimensions such as responsiveness and reliability affect patients' satisfaction that is directly related to patients' loyalty to the hospital. Markovic et al. (2014) investigate the influence of service quality on customer satisfaction in the health sector using the SERVQUAL model and confirm the usefulness of the model in terms of reliability and validity for quality measurement in the health sector. The results of their research indicate that users who observe higher level of services quality show greater satisfaction as well as greater degree of loyalty to the medical service provider. In the research of the interdependence of electronic services quality and customer satisfaction, Ćuzovic \& Sokolov-Mladenović (2009) point out that the SERVQUAL model has been applied to the field of electronic commerce, and that the quality dimensions in this field are viewed from a broader perspective, including tangibility, reliability, security, empathy, information quality and communication integrity, whereby if there is a positive perception of quality dimensions by consumers, the electronic service is of high quality.

The business environment of banks in modern economic conditions is characterised by rapid changes as well as increased competition, whereby services quality expands as a key factor of survival and business development. In such business environment banks must concentrate their efforts towards improving their services quality and satisfying clients' needs (Radomir et al., 2011). Clients satisfaction, as the basis of success in highly competitive market, is mostly dependent on service quality. To achieve a high level of clients satisfaction, a high level of service quality must be delivered, why service quality became an important tool to measure clients satisfaction (Shanka, 2012). In order to deal with strong competition, the management of the banks must leave the old strategies and work to improve clients satisfaction, why it's important to investigate clients perceptions on the service qualiy in oder to estimate whether banks are meeting the clients expectations (Srinivas \& Rao, 2018). In other words, it is important to measure service quality in order to determine its influence on clients' satisfaction and improvements that need to be made. Starting from the above mentioned, Bahia \& Nantel (2000), based on the SERVQUAL model, are developing a new model for measuring banking services quality with a population that includes six dimensions: efficiency and security, access, price, tactility, portfolio service and reliability. Using the SERVQUAL model, Abdelghani (2012) came to the conclusion that responsiveness, assurance and empathy are important dimensions that users are considering in assessing services quality provided by Moroccan banks. When considering dependence between service quality dimension and satisfaction of banks' clients, Van Quyet et al. (2015) as well as Rijwani et al. (2017) came to the conclusion that all five dimensions of the SERVQUAL model have statistically significant influence on customer satisfaction. Using a modified SERVQUAL model for measuring electronic banking services quality in Serbia, Gasevic et al. 
(2016) confirmed the influence of security, ease of use and responsibility on satisfaction, while reliability, empathy and website content have non-significant influence on satisfaction.

In order to be successful in the market, it is important for banks not only to attract new clients but also to retain the existing ones. The first step towards retaining clients is to achieve their satisfaction, which leads to clients loyalty. Loyalty is one of the most important structure in service marketing since loyal clients are the base of any business (Mosahab et al., 2010). According to Chocholáková et al. (2015), loyal clients are more interested in the services of their banks when considering investments in the financial market, more likely to deposit their savings to their bank, to take out a mortgage from their bank and to use other banking products and services from their bank. A review of literature makes it possible to perceive the existence of link between service quality and loyalty of the banks' clients. Kheng et al. (2010) using the SERVQUAL model came to the conclusion that improving banking services quality can increase clients' loyalty and that direct, statistically significant influence on clients loyalty in Malaysia have reliability, empathy and assurance, while tangible elements of service quality and responsiveness have no influence. Three years later, Albarqu (2013) came to the same results, analysing the influence of local bank service quality in Riyadh, Saudi Arabia on the loyalty of their clients. Alafeshat \& Alola (2018) in their work confirm the influence of all dimensions of the SERVQUAL service quality model on customer satisfaction in the Jordanian Commercial Bank, while when considering clients' loyalty this influence is absent only on reliability dimension.

\section{Research methodology}

For the purpose of measuring clients attitudes regarding banking services quality, the survey method, questionnaire technique was applied. This data collection technique was used because it can obtain data from a relatively big sample within a small amount of time and at low cost per participant, it is easy to develop and administer and allows the researcher to be flexible in the type and number of questions used in survey (Chrysochou, 2017). The questionnaire was filled out by clients of banks operating on the territory of Kragujevac, Central Serbia, in the period from September 15 to October 23, 2018, personally. Simple random sample technique for sampling was applied. The questionnaire includes three parts. The first part of the questionnaire refers to the variables of the SERVQUAL model (tangibility, reliability, responsiveness, assurance and empathy) i.e. the statements that make them, the second part of the questionnaire includes statements relating to the satisfaction and loyalty of clients, while the third part of the questionnaire refers to data on respondents (gender, age and frequency of visit to the bank). The sample includes 276 clients, of which 145 are female (52.5\%) and 131 male clients (47.5\%). As for the age, the youngest clients (from 18-24 years old) include $21.7 \%$ 
of the sample (60 clients), from 25-44 years have 143 clients $(51.8 \%), 34$ clients have between 45 and 54 years $(12.3 \%)$ while 39 clients have 55 or more years (14.1\%). The sample is dominated by clients who visit the bank once a month (110 clients or $39.9 \%)$, 97 clients visit their bank twice a month (35.1\%), 44 clients go to the bank up to three times a month $(15.9 \%)$ while more than three times a month in bank go 25 respondents or $9.1 \%$ of the sample.

The banking services quality in the paper is viewed through five dimensions of the SERVQUAL model (Parasuraman et al., 1988), with the modification of the model being made by adding new statements to some dimensions. In this regard, tangibility as the first dimension of the model is measured with four statements, of which three are from the model and one is additional, reliability is measured with three statements, two of which are from the model and one is additional, variables responsiveness and empathy are measured with three statements from the model while variable assurance is measured with two statements from the model. Satisfaction and loyalty are both measured with two statements taken and adapted from the relevant literature (Lewis \& Soureli, 2006; Marinkovic et al., 2011).

Primary data analysis was conducted in the statistical software SPSS. The analysis used are first descriptive statistics for determining the convenience and homogeneity of the respondents' attitudes, then reliability analysis of the SERVQUAL model variables and satisfaction and loyalty as a consumer behaviour aspects, followed by a correlation analysis that examined the degree of linear dependence between variables of the survey and in the end multiple regression analysis in order to test the influence of the observed dimensions of banking services quality on clients' satisfaction and loyalty.

\section{Research results}

Descriptive statistical analysis was conducted in order to determine the convenience and homogeneity of the respondents' attitudes when observed statements that measure banking services quality dimensions and satisfaction and loyalty, while the reliability analysis determines the internal consistency of the statements. The convenience and homogeneity of attitudes are determined on the basis of arithmetic mean and standard deviation, respectively, while reliability is determined based on the value of Cronbach's alpha coefficient. The results of these analyses are shown in Tables 1 and 2. 
Table 1. Descriptive statistics and reliability analysis of SERVQUAL model

\begin{tabular}{|c|c|c|c|c|}
\hline $\begin{array}{l}\text { SERVQUAL } \\
\text { model variables }\end{array}$ & Statements & Mean & $\begin{array}{l}\text { Standard } \\
\text { deviation }\end{array}$ & $\begin{array}{l}\text { Cronbach's } \\
\text { alpha }\end{array}$ \\
\hline \multirow{4}{*}{ Tangibility } & $\begin{array}{l}\text { 1. The banks' interior is } \\
\text { visually appealing. }\end{array}$ & 5,11 & 1,62 & \multirow{4}{*}{0,886} \\
\hline & $\begin{array}{l}\text { 2. The bank uses modern } \\
\text { equipment. }\end{array}$ & 5,44 & 1,47 & \\
\hline & $\begin{array}{l}\text { 3. The bank has sufficient } \\
\text { counters and offices. }\end{array}$ & 4,90 & 1,83 & \\
\hline & $\begin{array}{l}\text { 4. Employees in the bank } \\
\text { are neat and professionally } \\
\text { dressed. }\end{array}$ & 5,23 & 1,62 & \\
\hline \multirow{3}{*}{ Reliability } & $\begin{array}{l}\text { 5. Employees in the bank } \\
\text { show understanding for } \\
\text { clients problems. }\end{array}$ & 5,41 & 1,55 & \multirow{3}{*}{0,898} \\
\hline & $\begin{array}{l}\text { 6. Employees in the bank } \\
\text { provide a service in a } \\
\text { promised time. }\end{array}$ & 5,45 & 1,56 & \\
\hline & $\begin{array}{l}\text { 7. You believe that the } \\
\text { bank is reliable in } \\
\text { providing services. }\end{array}$ & 5,32 & 1,56 & \\
\hline \multirow{3}{*}{ Responsiveness } & $\begin{array}{l}\text { 8. Employees in the bank } \\
\text { are always ready to help } \\
\text { clients. }\end{array}$ & 5,35 & 1,58 & \multirow{3}{*}{0,896} \\
\hline & $\begin{array}{l}\text { 9. Employees in the bank } \\
\text { provide fast service. }\end{array}$ & 5,28 & 1,61 & \\
\hline & $\begin{array}{l}\text { 10. Employees in the bank } \\
\text { are always ready to answer } \\
\text { clients questions. }\end{array}$ & 5,46 & 1,51 & \\
\hline \multirow[b]{2}{*}{ Assurance } & $\begin{array}{l}\text { 11. You feel secure during } \\
\text { cooperation with the bank. }\end{array}$ & 5,40 & 1,60 & \multirow[b]{2}{*}{0,843} \\
\hline & $\begin{array}{l}\text { 12. Employees in the bank } \\
\text { are kind to clients. }\end{array}$ & 5,52 & 1,48 & \\
\hline \multirow{3}{*}{ Empathy } & $\begin{array}{l}\text { 13. Employees in the bank } \\
\text { devote individual attention } \\
\text { to clients. }\end{array}$ & 5,35 & 1,55 & \multirow{3}{*}{0,902} \\
\hline & $\begin{array}{l}\text { 14. Employees in the bank } \\
\text { understand the specific } \\
\text { needs of clients. }\end{array}$ & 5,31 & 1,55 & \\
\hline & $\begin{array}{l}\text { 15. Employees in the bank } \\
\text { are the most important } \\
\text { clients' interests. }\end{array}$ & 5,29 & 1,69 & \\
\hline
\end{tabular}

Source: authors' calculation 
Table 1 shows the obtained values of arithmetic means and standard deviations for the statements that measure dimensions of the SERVQUAL model. High values of arithmetic means show that for statements Employees in the bank are kind to clients and Employees in the bank are always ready to answer clients questions the attitudes of clients are the most favourable, while the least favourable attitudes occur in the statements The bank has sufficient counters and offices and The banks' interior is visually appealing for which the values of arithmetic means are the lowest. When considering the degree of agreement or the homogeneity of the attitudes of the respondents, results show that clients most agree on statements The bank uses modern equipment and Employees in the bank are kind to clients, because for these statements the values of standard deviation are the lowest, while the least agree on statements The bank has sufficient counters and offices and Employees in the bank are the most important clients' interests due to the highest values of standard deviations. When it comes to reliability of dimensions, all obtained values of Cronbach's alpha coefficient are above 0.7 , indicating their high reliability, where the most reliable dimension is empathy while the least reliable dimension is assurance.

Table 2. Descriptive statistics and reliability analysis of satisfaction and loyalty

\begin{tabular}{|c|c|c|c|c|}
\hline Variable & Statements & Mean & $\begin{array}{l}\text { Standard } \\
\text { deviation }\end{array}$ & $\begin{array}{l}\text { Cronbach's } \\
\text { alpha }\end{array}$ \\
\hline \multirow{2}{*}{ Satisfaction } & $\begin{array}{l}\text { 16. Your complete impression and } \\
\text { experience with the bank make } \\
\text { you very satisfied. }\end{array}$ & 5,29 & 1,52 & \multirow{2}{*}{0,863} \\
\hline & $\begin{array}{l}17 . \text { The quality of services provided } \\
\text { by the bank is far above expected. }\end{array}$ & 5,18 & 1,58 & \\
\hline \multirow[b]{2}{*}{ Loyalty } & $\begin{array}{l}\text { 18. You will continue to use the } \\
\text { services of the bank in the future. }\end{array}$ & 5,48 & 1,55 & \multirow[b]{2}{*}{0,866} \\
\hline & $\begin{array}{l}\text { 19. You are ready to recommend } \\
\text { the bank and its services to friends. }\end{array}$ & 5,39 & 1,62 & \\
\hline
\end{tabular}

Source: authors' calculation

Descriptive statistics conducted for statements that measure satisfaction and loyalty indicate that the most favorable customer attitudes occur for statement You will continue to use the services of the bank in the future due to the highest value of arithmetic mean, while the lowest value of arithmetic mean for statement The quality of services provided by the bank is far above expected indicates that $\mathrm{n}$ this statement according to the clients' attitudes are least favourable. On the other hand, the statement that respondents agree on the most is Your complete impression and experience with the bank make you very satisfied where value of standard deviation is the lowest, while respondents least agree with statement You are ready to 
recommend the bank and its services to friends because it has the highest standard deviation value. The results of reliability analysis show that variable loyalty has higher degree of reliability compared to variable satisfaction due to a slightly higher value of Cronbach's alpha coefficient.

By correlation analysis the degree of linear dependence between variables based on the Pearson correlation coefficient value was tested. The results of this analysis are given in Table 3.

Table 3. Correlation analysis

\begin{tabular}{|c|c|c|c|c|c|c|c||}
\hline & Tan. & Rel. & Resp. & Assur. & Emp. & Sat. & Loy. \\
\hline Tangibility & 1 & $0.808^{*}$ & $0.797^{*}$ & $0.780^{*}$ & $0.808^{*}$ & $0.794^{*}$ & $0.798^{*}$ \\
\hline Reliability & $0.808^{*}$ & 1 & $0.912^{*}$ & $0.892^{*}$ & $0.875^{*}$ & $0.858^{*}$ & $0.872^{*}$ \\
\hline Responsiveness & $0.797^{*}$ & $0.912^{*}$ & 1 & $0.888^{*}$ & $0.875^{*}$ & $0.860^{*}$ & $0.875^{*}$ \\
\hline Assurance & $0.780^{*}$ & $0.892^{*}$ & $0.888^{*}$ & 1 & $0.891^{*}$ & $0.872^{*}$ & $0.858^{*}$ \\
\hline Empathy & $0.808^{*}$ & $0.875^{*}$ & $0.875^{*}$ & $0.891^{*}$ & 1 & $0.891^{*}$ & $0.858^{*}$ \\
\hline Satisfaction & $0.794^{*}$ & $0.858^{*}$ & $0.860^{*}$ & $0.872^{*}$ & $0.891^{*}$ & 1 & $0.870^{*}$ \\
\hline Loyalty & $0.798^{*}$ & $0.872^{*}$ & $0.875^{*}$ & $0.858^{*}$ & $0.858^{*}$ & $0.870^{*}$ & 1 \\
\hline \hline
\end{tabular}

Source: authors' calculation

The results presented in Table 3 show above all that there is a statistically significant degree of linear dependence between all pairs of variables, that is, that all obtained values of correlation coefficient are statistically significant with a probability of $99 \%$. Between all pairs of variables there is strong linear dependence since values of Pearson coefficient are in the interval of 0.6-1. At the highest level variables responsiveness and reliability $(\alpha=0.912 *)$ are correlated, while the weakest correlation exists between variables assurance and tangibility $\left(\alpha=0.780^{*}\right)$.

Testing the influence of the SERVQUAL model dimensions on clients' satisfaction and loyalty was performed using multiple regression analysis (Tables 4 and 5). The suitability of the data for conducting this analysis was tested using VIF coefficient which value in all pairs of variables should be less than 5 (Akinwande et al., 2015), but the literature also accepts the upper value of 10 (Hair et al., 1995; Yoo et al., 2014). As the results in Tables 4 and 5 show that values of VIF coefficient in all pairs are less than 10 , the data are considered to be suitable for analysis. 
Table 4. Multiple regression analysis (Dependent Variable Satisfaction)

\begin{tabular}{||c|c|c|c|c|c||}
\hline Independent variable & $\mathrm{T}$ & $\mathrm{B}$ & $\mathrm{Sig}$ & $\mathrm{VIF}$ & \multirow{2}{*}{$\mathrm{R}^{2}$} \\
\cline { 1 - 5 } Tangibility & 2.499 & 0.112 & $0.013 *$ & 3.353 & \\
\cline { 1 - 4 } Reliability & 1.291 & 0.090 & 0.198 & 8.027 & \\
\cline { 1 - 4 } Responsiveness & 2.122 & 0.144 & $0.035^{*}$ & 7.603 & \multirow{2}{*}{$0.838^{*}$} \\
\cline { 1 - 4 } Assurance & 3.414 & 0.223 & $0.001 *$ & 7.062 & \\
\cline { 1 - 4 } Empathy & 6.367 & 0.397 & $0.000^{*}$ & 6.475 & \\
\hline
\end{tabular}

Source: authors' calculation

Observing the results of the first regression analysis, one can first notice high and statistically significant value of $\mathrm{R}^{2}$ determination coefficient which shows that $83.8 \%$ of variability of satisfaction is explained by this regression model. Regarding the influence of the SERVQUAL model dimensions as independent variables on dependent variable satisfaction, based on the Sig value from the fourth column of Table 4 it can be seen that it is statistically significant for all variables except for variable reliability. The strongest influence on satisfaction has variable empathy $(\beta=0.397)$ while the weakest influence has variable tangibility $(\beta=0.112)$.

Table 5. Multiple regression analysis (Dependent Variable Loyalty)

\begin{tabular}{||c|c|c|c|c|c||}
\hline Independent variable & $\mathrm{T}$ & $\mathrm{B}$ & $\mathrm{Sig}$ & $\mathrm{VIF}$ & \multirow{2}{*}{$\mathrm{R}^{2}$} \\
\hline Tangibility & 3.090 & 0.144 & $0.002^{*}$ & 3.353 & \\
\cline { 1 - 4 } Reliability & 2.865 & 0.207 & $0.004^{*}$ & 8.027 & \multirow{2}{*}{$0.825^{*}$} \\
\cline { 1 - 4 } Responsiveness & 3.895 & 0.273 & $0.000^{*}$ & 7.603 & \\
\hline Assurance & 2.298 & 0.156 & $0.022^{*}$ & 7.062 & \\
\hline Empathy & 2.823 & 0.183 & $0.005^{*}$ & 6.475 & \\
\hline
\end{tabular}

Source: authors' calculation

The second regression analysis also revealed a statistically significant value of $\mathrm{R}^{2}$ determination coefficient based on which it can be seen that $82.5 \%$ of variability of dependent variable loyalty was explained by the observed regression model. When considering the influence of independent variables on dependent variable, the Sig value from the fourth column of Table 5 shows that it is statistically significant for all variables and that it is the strongest when it comes to responsiveness $(\beta=0.273)$ and the weakest for tangibility $(\beta=0.144)$. 


\section{Conclusion}

Banks operating in todays' complex environment, where the pressure of competition is inevitable and strong, must continuously work on improving their business systems, raising the level of service quality and fostering satisfaction and long-term loyalty of their clients in order to achieve successful and profitable cooperation with them. Starting from the significance of various aspects of offer quality for developing long-term relationships with clients, research was conducted in order to determine the effects of banking services quality dimensions on clients' satisfaction and loyalty using the SERVQUAL model, whereby modification of the model was made by adding new statements to some dimensions. The influence of dimensions on satisfaction and loyalty was tested by using multiple regression analysis.

Results of the research showed that satisfaction of the bank clients is most strongly determined by empathy and the weakest by tangibility, that is, by the interior and exterior of the bank, the appearance of employees and so on. An interesting result is that dimension reliability that relates to understanding clients' problems and compliance with agreed deadlines has no statistically significant influence on clients' satisfaction, which is consistent with results of the research by Gasevic et al. (2016), but opposite to the results of Al Afeshat \& Alola (2018) which confirmed that there is statistically significant influence of all dimensions of SERVQUAL model on clients' satisfaction. On the other hand, clients' loyalty is most strongly influenced by responsiveness, and the weakest is, as well as satisfaction, under the influence of tangibility. This result does not coincide with results of research by the authors such as Kheng et al. (2010) or Albarqu (2013) that did not confirme the influence of tangibility and reliability on clients' loyalty. The methodological framework that has been applied in this paper and results obtained can be used as starting point for future research in domain of banking services quality. The analysis of influence of some of the most important dimensions of banking services quality, which at the same time make the SERVQUAL model as one of the most frequently used models for measuring services quality, is useful in terms of complementing the existing scientific knowledge, as well as from the angle of management of banks that the results of this research can use to improve bank services quality in line with influence that its aspects have on clients' attitudes. By analysing these influences several recommendations to bank managers can be highlighted. First of all, it is necessary before all to maintain the existing level of quality dimensions, since all of them influence clients' loyalty. The same recommendation is also given when considering tangibility, responsiveness, assurance and empathy as statistically significant determinants of clients' satisfaction. On the other hand, it is recommended that appropriate investments be made to improve the tangible aspects of offer quality such as interior, exterior, employee appearance and especially the capacity of the space, since these aspects have the weakest influence 
first on satisfaction and, consequently, on clients' loyalty. It is also desirable to improve aspects related to reliability in the provision of banking services through appropriate employee training in order to encourage higher degree of clients' satisfaction. As limitations of work, small sample of respondents and its unequal structure may have been identified, which might influenced some results, using less statements than the original SERVQUAL model and observing only satisfaction and loyalty, or neglecting other aspects such as experience or intentions of clients regarding the use of banking services. In this regard, the recommendation for future research is primarily related to the increase of the sample, with particular reference to its structure. Also, future papers can be based on the application of modified SERVQUAL model not only by adding new statements, but also by adding new variables such as rows of waiting, employee kindness, etc. Considering that it is assumed that clients in this survey evaluated services of the bank they are most often visiting, in future papers the analysis of services quality for several competing banks can be done, which would certainly enable to obtain more precise answers and better results and conclusions.

\section{References}

Abdelghani, E. (2012). Applying SERVQUAL to banking services: an exploratory study in Morocco. Studies in Business \& Economics, 7(1), 62-72.

Akinwande, M. O., Dikko, H. G., \& Samson, A. (2015). Variance inflation factor: As a condition for the inclusion of suppressor variable (s) in regression analysis. Open Journal of Statistics, 5(07), 754-767. DOI: 10.4236/ojs.2015.57075

Alafeshat, R. \& Alola, V. U. (2018). Investigating the nexus of service quality and customer loyalty in banking industry via the mediating role of customer satisfaction. Academic Journal of Economic Studies, 4(3), 167-176.

Albarq, A. N. (2013). Applying a SERVQUAL model to measure the impact of service quality on customer loyalty among local Saudi banks in Riyadh. American Journal of Industrial and Business Management, 3(8), 700-707. DOI: 10.4236/ajibm.2013.38079

Bahia, K., \& Nantel, J. (2000). A reliable and valid measurement scale for the perceived service quality of banks. International journal of bank marketing, 18(2), 84-91. https://doi.org/10.1108/02652320010322994

Cronin, J., \& Taylor, S. (1992). Measuring Service Quality: A Reexaminationand Extension. Journal of Marketing, 56(3), 55-68. DOI: 10.2307/1252296

Chocholáková, A., Gabčová, L., Belás, J., \& Sipko, J. (2015). Bank Customers’ Satisfaction, Customers' Loyalty and Additional Purchases of Banking Products and Services. A Case Study from the Czech Republic. Economics and Sociology, 8(3), 82-94. doi: 10.14254/2071-789X.2015/8-3/6

Chrysochou, P. (2017). Consumer behavior research methods. In: Emilien, G., Weitkunat, R. \& Lüdicke, F. (Eds.), Consumer Perception of Product Risks and Benefits (pp. 409-428). Switzerland: Springer International Publishing. DOI: 10.1007/978-3-319-50530-5_22

Ćuzovic, S., \& Sokolov-Mladenović, S. (2009). Unapređenje kvaliteta elektronske usluge u funkciji satisfakcije potrošača. Ekonomske teme, 47(2), 43-58. 
Furrer, O., Liu, B. S., \& Sudharshan, D. (2000). The relationships between culture and service quality perceptions: Basis for cross-cultural market segmentation and resource allocation. Journal of service research, 2(4), 355-371.

Grönroos, C. (1984). A service quality model and its marketing implications. European Journal of marketing, 18(4), 36-44. DOI: 10.1108/EUM0000000004784

Gasevic, D., Vranjes, M., \& Drinic, D. (2016). Identification of key determinants of satisfaction of users of electronic banking services. Economic Themes, 54(2), 301-321.

Hair, J. F. Jr., Anderson, R. E., Tatham, R. L. \& Black, W. C. (1995). Multivariate Data Analysis ( $3^{\text {rd }}$ ed). New York: Macmillan.

Kheng, L. L., Mahamad, O., Ramayah, T., \& Mosahab, R. (2010). The impact of service quality on customer loyalty: A study of banks in Penang, Malaysia. International journal of marketing studies, 2(2), 57-66. DOI:10.5539/ijms.v2n2p57

Lewis, B. R., \& Soureli, M. (2006). The antecedents of consumer loyalty in retail banking. Journal of Consumer Behaviour: An International Research Review, 5(1), 15-31. https://doi.org/10.1002/cb.46

Ljumovic, I., Pavlovic, V. \& Cvijanovic, M. J. (2014). Two aspects of concentration in Serbian banking sector. Industrija, 42(3), 61-77. DOI: 10.5937/industrija42-5867

Marinković, V., \& Senić, V. (2012). Analiza elemenata kvaliteta usluga u korporativnom bankarstvu. Ekonomski horizonti, 14(1), 13-22. DOI:10.5937/ekonhor1201013M

Marinkovic, V., Senic, V., Kocic, M., \& Sapic, S. (2011). Investigating the impact of SERVQUAL dimensions on customer satisfaction: The lessons learnt from Serbian travel agencies. International Journal of Tourism Research, 15(2), 184-196. DOI: $10.1002 /$ jtr.884

Markovic, S., Loncaric, D., \& Loncaric, D. (2014). Service quality and customer satisfaction in the health care industry-towards health tourism market. Tourism and hospitality management, 20(2), 155-170.

Meesala, A., \& Paul, J. (2016). Service quality, consumer satisfaction and loyalty in hospitals: Thinking for the future. Journal of Retailing and Consumer Services, 40, 261-269. https://doi.org/10.1016/j.jretconser.2016.10.011

Mosahab, R., Mahamad, O., \& Ramayah, T. (2010). Service quality, customer satisfaction and loyalty: A test of mediation. International business research, 3(4), 72-80. doi: 10.5539/ibr.v3n4p72

Narodna banka Srbije. (2017). Izveštaj za treće tromesečje 2017. godine, preuzeto sa: https://www.nbs.rs/internet/latinica/55/55_4/kvartalni_izvestaj_III_17.pdf, pristupljeno: 28. Novembra 2018.

Narodna banka Srbije. (2018). Izveštaj za prvo tromesečje 2018. godine, preuzeto sa: https://www.nbs.rs/internet/latinica/55/55_4/kvartalni_izvestaj_I_18.pdf, pristupljeno: 28. Novembra 2018.

Parasuraman, A., Zeithaml, V. A., \& Berry, L. L. (1985). A conceptual model of service quality and its implications for future research. The Journal of Marketing, 49(4), 4150. DOI: $10.2307 / 1251430$

Parasuraman, A., Zeithaml, V. A., \& Berry, L. L. (1988). Servqual: A multiple-item scale for measuring consumer perceptions of service quality. Journal of retailing, 64(1), 12-40.

Radojević, P., \& Marjanović, D. (2011). Kvalitet usluga u bankarstvu: nesaglasnosti, odrednice i istraživačke tehnike za unapređenje kvaliteta. Bankarstvo, 40(7-8), 34-59.

Radomir L., Wilson A., \& Scridon A. M. (2011). Improving Bank Quality Dimensions to Increase Customer Satisfaction. Management and Marketing Journal, 9(1), 126-148. 
Rijwani, P., Patel, R. \& Patel, N. (2017). Service quality and customer satisfaction: Study of Indian banks using SERVQUAL. International Journal of Economic Research, 14(18), 199-211.

Saleh, F., \& Ryan, C. (1991). Analysing service quality in the hospitality industry using the SERVQUAL model. Service Industries Journal, 11(3), 324-345. https://doi.org/10.1080/02642069100000049

Shanka, M. S. (2012). Bank service quality, customer satisfaction and loyalty in Ethiopian banking sector. Journal of Business Administration and Management Sciences Research, 1(1), 001-009.

Srinivas, D. \& Rao, N. H. (2018). Service Quality in Commercial Banks: A Study of Public Sector Banks in Warangal District. Journal of Management, 5(4), 9-17.

Stevens, P., Knutson, B., \& Patton, M. (1995). DINESERV: A tool for measuring service quality in restaurants. Cornell hotel and restaurant administration quarterly, 36(2), 56-60. https://doi.org/10.1016/0010-8804(95)93844-K

Van Quyet, T., Vinh, N. Q., \& Chang, T. (2015). Service quality effects on customer satisfaction in banking industry. International Journal of u-and e-Service, Science and Technology, 8(8), 199-206. DOI: 10.14257/ijunesst.2015.8.8.20

Yoo, W., Mayberry, R., Bae, S., Singh, K., He, Q. P., \& Lillard Jr, J. W. (2014). A study of effects of multicollinearity in the multivariable analysis. International journal of applied science and technology, 4(5), 9-19.

Zelenović, V., Vitomir, J., \& Radović, M. (2017). SERQUAL model u funkciji unapredjenja kvaliteta bankarskog poslovanja. Zbornik radova naučnog skupa EKONBIZ, (17), 34-43.

\section{MERENJE STAVOVA KLIJENATA O KVALITETU BANKARSKIH USLUGA PRIMENOM SERVQUAL MODELA}

Apstrakt: Ekonomska kriza i pojava sve većeg broja konkurenata u bankarskom sektoru, uslovila je potrebu da banke bolje upoznaju svoje klijente i ostvaruju čvršću saradnju sa njima. Osnovu opstanka i profitabilnog poslovanja banaka čini postizanje visokog kvaliteta ponude koji je u funkciji razvoja dugoročnih odnosa. Cilj rada odnosi se na utvrđivanje efekata dimenzija kvaliteta usluga banaka na satisfakciju i lojalnost klijenata primenom modifikovanog SERVQUAL modela. Analiza je sprovedena obradom primarnih podataka u statističkom softveru SPSS gde je sprovedeno više statističkih analiza. $\mathrm{Na}$ osnovu višestruke regresione analize došlo se do rezultata da najjači uticaj na satisfakciju klijenata ima varijabla empatija a najslabiji varijabla opipljivost, dok varijabla pouzdanost nema uticaj. S druge strane, na lojalnost klijenata najjače utiče varijabla odgovornost dok najslabiji uticaj, kao i na satisfakciju, ima varijabla opipljivost. Rad ukazuje na značaj unapređenja kvaliteta bankarskih usluga kako bi se postigao viši stepen satisfakcije i dugoročna lojalnost klijenata, što je posebno značajno kada se radi o dimenzijama koje imaju slab ili nikakav uticaj na posmatrane aspekte ponašanja potrošača.

Ključne reči: kvalitet usluga, banke, klijenti, SERVQUAL model, satisfakcija, lojalnost 


\section{Appendix}

Tangibility

1. The banks' interior is visually appealing.

2. The bank uses modern equipment.

3. The bank has sufficient counters and offices.

4. Employees in the bank are neat and professionally dressed.

Reliability

5. Employees in the bank show understanding for clients problems.

6. Employees in the bank provide a service in a promised time.

7. You believe that the bank is reliable in providing services.

Responsiveness

8. Employees in the bank are always ready to help clients.

9. Employees in the bank provide fast service.

10. Employees in the bank are always ready to answer clients questions.

Assurance

11. You feel secure during cooperation with the bank.

12. Employees in the bank are kind to clients.

Empathy

13. Employees in the bank devote individual attention to clients.

14. Employees in the bank understand the specific needs of clients.

15. Employees in the bank are the most important clients' interests.

Satisfaction

16. Your complete impression and experience with the bank make you very satisfied.

17. The quality of services provided by the bank is far above expected.

Loyalty

18. You will continue to use the services of the bank in the future.

19. You are ready to recommend the bank and its services to friends. 
Table 6. Sample structure

\begin{tabular}{|c|c|}
\hline Gender & $\begin{array}{l}\text { 1. Female } \\
\text { 2. Male }\end{array}$ \\
\hline Age & $\begin{array}{l}\text { 1. } 18-24 \text { years } \\
\text { 2. } 25-44 \text { years } \\
\text { 3. } 45-54 \text { years } \\
\text { 4. } 55 \text { and more years }\end{array}$ \\
\hline Frequency of visit to the bank & $\begin{array}{l}\text { 1. Once a month } \\
\text { 2. Twice a month } \\
\text { 3. Three times a month } \\
\text { 4. More than three times a month }\end{array}$ \\
\hline
\end{tabular}

Source: authors

\section{Authors' biographies}

Jovana Savić works as junior-researcher at the Faculty of Economics, University of Kragujevac. In the current project cycle of the Ministry of Education, Science and Technological Development of the Republic of Serbia she is engaged in a project No. III 41010. In the previous scientific and research work she has published several co-author papers in relevant scientific journals and collections of scientific conferences.

Nevena Veselinović works as junior-researcher at the Faculty of Management in Zajecar, Megatrend University. In the current project cycle of the Ministry of Education, Science and Technological Development of the Republic of Serbia she is engaged in a project No. III 41010. The previous scientific work is characterized by the presence at various scientific conferences which resulted in the publication of scientific papers in various collections. Nevena is a member of the Society of Economists of Kragujevac. 